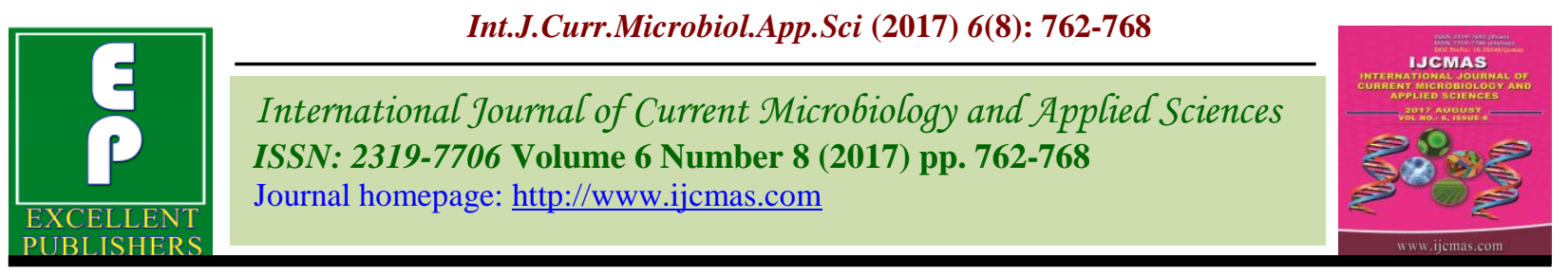

Original Research Article

https://doi.org/10.20546/ijcmas.2017.608.097

\title{
A Study on Constraints in Production and Marketing of Pulses and Suggest Suitable Policy Measures
}

\author{
Rajeev Singh ${ }^{1}$, Gyan Prakesh Singh ${ }^{1}$, Praveen Kumar Sahu ${ }^{1}$ and Avanish Kumar Singh ${ }^{2 *}$ \\ ${ }^{1}$ Department of Agricultural Economics, N.D.U.A. \& T. Kumarganj, Faizabad, U.P, India \\ ${ }^{2}$ ICAR-Agricultural Technology Application Research Institute, Kanpur, U.P, India \\ *Corresponding author
}

\section{A B S T R A C T}

Keywords

Functional analysis, Tabular analysis, Weighted mean.

Article Info

Accepted: 14 June 2017 Available Online: 10 August 2017
This study was conducted in Thekma block of district Azamgarh, Uttar Pradesh. Following purposing random sampling technique, 100 sample farmers were selected and interviewed for collection of data, average land holding size corresponding 0.44 marginal, 1.57 small and 3.24 medium size group of farm. In various problems, technical problem ranked first followed by marketing availability of inputs in time, Anny other problems (Blue Bull, Natural calamity and canal problem) agro- climatic problem and miscellaneous problem. Henry Garrett's ranking methods HG technique is use to evaluate the reason for switching over from LIC to other private company in the feature in this method, policy holder or asked to rank all the variables such as thing, length.

\section{Introduction}

Pulses play a vital role in our lives. The word "Pulse" is derived from the Latin word "Puls" meaning pottage i.e. seeds boiled to make porridge or thick soup. Pulses are the cheapest source of dietary proteins. The high content of protein in pulses makes the diet more nutritive for vegetarian when taken with other cooked food items. Pulses contain the same amount of calories as cereals but the protein content varies. The protein content of pulses are twice that of cereals (20-25\%) and almost equal to that of meat and poultry. But the quality of protein content is inferior to animal protein. They provide the same amount of calories as cereals, which are staple food all over the world. If we take $100 \mathrm{~g}$ of dry pulses, it would contain about 350Kcal of energy. Pulses are good sources of proteins and commonly called the poor man's meat (Reddy, 2010). The frequency of pulses consumption is much higher than any other source of protein; about 89.00 percent population consume pulses at least once a week, while only 35.40 percent of persons consume fish or chicken/meat at least once a week in India (IIPS, ORC Macro, 2007).

At the world level pulses are grown in an area of 78 million hectares with an annual production of 70 million tonnes (MT) and productivity of $908 \mathrm{~kg} /$ hectare (FAO and Agricultural org. 2012). In India pulses are 
grown on 22.23 million hectares of area with an annual production of 13.15 million tonnes (MT). India accounts for $33 \%$ of the world's area under pulses and $22 \%$ of the world production of pulses. About $90.00 \%$ of the global pigeonpea, $65.00 \%$ of chickpea and $37.00 \%$ of lentil area falls in India, corresponding to $93.00,68.00$ and 32.00 percent; of the global production, respectively (FAO Stat 2011).

Pulses are grown globally covering large dimension of about 70.50 million hectares in area with a total production of 57.27 million tonnes. Among different pulse producing countries, India ranks first having $29.96 \%$ of the total pulse acreage (2003-2004) though it contributes only $22.52 \%$ of the global pulse production. Over a dozen pulse crops are grown in the country and among these, Chickpea (Chana), Pigeon pea (Arhar), Mungbean (Moong) and Urdbean (Urd) are the most important, contributing total $86.00 \%$ (45.00\% of chickpea, $20.00 \%$ of pigeon pea, $10.00 \%$ of mungbean and $11.00 \%$ of urdbean) of the total pulses production (http://www.iipr.res.in/pe/introduction.asp).

India is the world's largest producer and the largest consumer of pulses. Pakistan, Canada, Burma, Australia and the United States, in that order, are significant exporters and are India's most significant suppliers. In spite of this, the net per capita availability of pulses has come down over years from 61.00 grams per day per person in 1951 to 32 grams per day per person in 2010. Thus the availability of pulse per capita per day has proportionately declined from $71.00 \mathrm{~g}$ (1955) to $36.90 \mathrm{~g}$ (1998) against the minimum requirement of $70.00 \mathrm{~g}$ per capita per day. There is not much possibility of the import of pulses in the country. The production of pulses has to be increased internally to meet the demand (Singh, 2012).
The trend in cross-border trade across the world is a major factor that influences pulses prices. Global trade in pulses increased almost six fold over the past three decades, from 1.70 million tonnes in 1981 to 12.40 million tonnes in 2011. With the value of global exports increasing more than 11 times over the same period, the unit value of exports increased almost four times from $\$ 133.8$ in 1961 to $\$ 654.6$ in 2011, representing an annual average increase of $7.60 \%$. On the other hand, the total production globally increased by just around $69.00 \%$ over the same half a century, from 40.35 million tonnes to 68.20 million tonnes.

Pulses are grown across the country with the highest share coming from Madhya Pradesh (24.00\%), Uttar Pradesh (16.00\%), Maharashtra (14.00\%), Andhra Pradesh (10.00\%), Karnataka (7.00\%) and Rajasthan $(6.00 \%)$, which together share about $77.00 \%$ of the total pulse production, while the remaining $23.00 \%$ is contributed by Gujarat, Chhattisgarh, Bihar, Orissa and Jharkhand.

Kumar (1998) projected pulses demand to be 30.90 MT, while Mittal (2006) projected 42.50 MT by 2020 and Indian Institute of Pulses Research (IIPR) in its vision 2030 projected pulses demand to be $32.00 \mathrm{MT}$ by the year 2030. The projected domestic production from this study is 20.00 MT by 2020.

As per Mittal, the required growth in domestic production (supply) of pulses is $6.51 \%$ per annum, while IIPR (2011) estimated the required growth rate in production to be $4.20 \%$ per annum to meet the growing demand. All these estimates indicate that, to bridge the gap between demand and supply, pulses production should grow at least 4-6\% per annum. However, the current growth rate is only $3.35 \%$ per annum (http://www.iipr.res.in/pe/introduction.asp). 
Area production and productivity of pulses in India were 23.47 million hactare, 18.34 million tonnes, and $781 \mathrm{~kg} / \mathrm{ha}$ respectively (National Council of Applied Economic Research New Delhi 2012-13). While area, production, and productivity in Uttar Pradesh were 2.31 million hectare, 1.71 million tones and $\quad 742.00 \mathrm{~kg} /$ hectare respectively (Directorate of Economics and Statistics, Department of Agriculture and cooperation 2013-14). Area, production, and productivity of pulse crops in Azamgarh district were 18533.00 hectare, 22352 metric tonnes, and $12.6 \mathrm{Q} /$ ha respectively during the period 2011-2012 (Statistical Report District Azamgarh 2011-12).

Area, production and productivity of major pulse crop Gram, Pea and Pigionpea in Azamgarh district were 3213.00, 6546.00 and 8397.00 hectare, 4220.00, 8922.00 and 8914.00 metric tonnes and 13.13, 13.63, and $10.62 \mathrm{Q} /$ ha respectively during the period 2011-12 (Statistical Report District Azamgarh 2011-12).

\section{Materials and Methods}

\section{Sampling technique}

The purposive com random sampling design was used for the selection of district, block, villages and respondents.

\section{Selection of district}

Azamgarh district of eastern U.P. was selected purposively to avoid the operational inconvenience of the investigator.

\section{Selection of block}

Out of twenty two blocks of selected district, one block namely Thekma having highest area under gram, pea and Pigeonpea was selected purposively.

\section{Selection of village}

A list of all the villages falling under selected block was prepared and arranged in ascending order according to area covered by gram, pea and Pigeonpea crop and five villages were selected randomly from the list (Table 1).

\section{Selection of respondents}

A list of gram, pea and Pigeonpea growers of selected villages were prepared along with their size of holding. Thus, the farm holding categorised into three size groups:

(1) Marginal: (Below 1.0 ha) (2) Small: (1.02.0 ha) (3) Medium: (2.0-4.0 ha). From this list a sample of 100 respondents were selected following the proportionate random sampling technique.

\section{Collection of data}

Primary data were collected through personal interview method on well pre-structured schedule specially designed for this study, while secondary data were collected from published/ unpublished record of district and blocks, headquarters, books, journals, periodicals, and news bulletins etc. among different pulses grown in Azamgarh district, three crops i.e. Gram, Pea, Pigeonpea (Arhar) had covered the highest are i.e. 3213.00, 6546.00, and 8397.00 hectare respectively. Thus these three crops of pulse were considered for study.

\section{Period of study}

The data pertained for the agriculture year 2015-2016.

\section{Analytical tools}

Analytical tools used for the analysis and interpretations of the data are given below. 


\section{Tabular analysis}

Tabular analysis was used to compare the different parameters among marginal, small and medium size group of the farmers.

Family composition, investment pattern; cropwise costs and returns etc. were computed and presented in tabular forms. In this computation weighted average was used.

$\mathrm{W} . \mathrm{A} .=\frac{\sum \mathrm{W}_{\mathrm{i}} \mathrm{X}_{\mathrm{i}}}{\sum \mathrm{W}_{\mathrm{i}}}$

Where,

W. A. = Weighted average

$\mathrm{Xi} \quad=$ Variable

Wi $=$ Weight of variable

\section{Henry Garrett's ranking methods} following formula

Present position $=100\left(\mathrm{R}_{\mathrm{ij}}-0.5\right) / \mathrm{N}_{\mathrm{j}}$

By using $G$ table, the present position is converted into score then each attributes the scores of each individual are added and then mean value are calculated to the rank position.

Where,

$\mathrm{R}_{\mathrm{ij}}=$ Rnak given for the $\mathrm{I}^{\text {th }}$ variable by $\mathrm{J}^{\text {th }}$ respondents

$\mathrm{N}_{\mathrm{j}}=$ Number of variables ranked by $\mathrm{J}^{\text {th }}$ respondents.

\section{Market for disposal of pulses production}

Most of the Agricultural produce (food grain and pulses) of the study area are disposed in the local market Thekma which is situated at
3-12 $\mathrm{km}$ distance from the sample villages. Few farmers having heavy marketable surplus also approach Jaunpur at district level market to dispose of their produce in whole sale market.

Thus the data related with marketing of pulses were recorded from a sizable number of market functionaries functioning in both the market.

\section{Marketable surplus}

The marketable and marketed surplus of Gram, Pea and Pigeon pea generated by different size groups of farms have been worked out as follow:

$\mathrm{MS}=\mathrm{P}-\mathrm{C}$

Where,

MS $=$ Marketable surplus

$\mathrm{P}=$ Total production of crop

$\mathrm{C}=$ Total requirement (family consumption, seeds, payment of wages to labours, cattle feed, payments to service providers persons such as carpenter, blacksmith, barber, washerman etc.).

\section{Marketed surplus}

The marketed surplus indicates the actual quantity of produce sold by the farmers in the markets has been worked out as follows:

$\mathrm{MT}=\mathrm{MS}+\mathrm{PS}+\mathrm{D}-\mathrm{L}$

Where,

MT $=$ Marketed surplus

MS = Marketable surplus actually sold

$\mathrm{D}=$ Distress sale 
PS = Post stock sold out, if any

$\mathrm{L}=$ Losses during storage and transmit Marketable surplus left for sale.

\section{Marketing efficiency}

Marketing efficiency was analyzed with following Shepherd's formula:

Marketing efficiency $(\mathrm{ME})=\frac{\mathrm{V}}{\mathrm{I}}$

Where,

$\mathrm{V}=$ Value of goods sold (consumer's price)

$\mathrm{I}=$ Total marketing costs (MC)

Higher the ratio, the more the marketing efficiency and vice-versa.

Price spread

"The difference between the price paid by the consumer and the net price received by producer was taken as the concept of spread".

\section{Results and Discussion}

\section{Constraints in production and marketing of pulses in study area}

The real picture of the problems realized and emphasized by the various size group of sample farms of the study area are presented in table 1. It is depicted from the table that problems related with lack of knowledge and skill stood $\mathrm{I}^{\text {st }}$ rank as it was emphasize by 30.09 per cent of the of the respondents followed by availability of inputs in time $\mathrm{III}^{\mathrm{rd}}$, constraints in marketing $\mathrm{II}^{\text {nd }}$ and other problem IV $^{\text {th }}$ ranks, correspondingly represented by $32.15,28.44$ and 18.31 percent of the respondent.
Suggestion to overcome the problems of production and marketing of pulses

\section{Suggestion to improve the production}

To solve the problem of knowledge and skill the farmers training demonstration, field visit and programme of farmers' interaction should be organized by the extension agencies working in the area.

Supply of inputs like quality seed, fertilizer, organic cultures, plant protection and weed control chemical should be assured by Govt. agency and private centres in times.

Financial institution should assure that the farmers can get required cash in their KCC accounts as and when needed.

Co-operative credit societies may play major role in supply of input like seed and fertilizers.

Irrigation sources like Govt. tubewell and canals should assure the availability of irrigation water with their full capacity.

To solve the problems of hired human labour the work of MNREGA should be stopped during peak season in the village.

\section{Suggestion to solve the problems of marketing}

Like rice and wheat pulse production should be purchase by the Govt. on MSP.

Minimum support price of the pulses should be announced well in advanced before sowing.

Pulse processing units should establish in the rural area to reduce the number of intermediary in the channel. 


\section{Constraints of major pulses on different size of farms}

\begin{tabular}{|c|c|c|c|c|c|c|c|c|c|c|c|c|}
\hline \multirow{3}{*}{$\begin{array}{l}\text { S. } \\
\text { No. }\end{array}$} & \multirow[t]{3}{*}{ Particulars } & \multicolumn{9}{|c|}{ Size of farms } & \multirow[t]{3}{*}{ Total } & \multirow{3}{*}{$\begin{array}{l}\text { Ran } \\
\mathbf{k} \\
\end{array}$} \\
\hline & & \multicolumn{3}{|c|}{ Marginal } & \multicolumn{3}{|c|}{ Small } & \multicolumn{3}{|c|}{ Medium } & & \\
\hline & & $\mathbf{A}$ & $\mathbf{N}$ & D & $\mathbf{A}$ & $\mathbf{N}$ & D & $\mathbf{A}$ & $\mathbf{N}$ & D & & \\
\hline A. & Technical Problems & $\begin{array}{l}669 \\
(28.59)\end{array}$ & $\begin{array}{l}504 \\
(41.58)\end{array}$ & $\begin{array}{l}47 \\
(10.65)\end{array}$ & $\begin{array}{l}30 \\
(19.23)\end{array}$ & $\begin{array}{l}40 \\
(37.73)\end{array}$ & $\begin{array}{l}18 \\
(25.71)\end{array}$ & $\begin{array}{l}18 \\
(18.18)\end{array}$ & $\begin{array}{l}22 \\
(42.30)\end{array}$ & $\begin{array}{l}13 \\
(28.26)\end{array}$ & $\begin{array}{l}1361 \\
(30.09)\end{array}$ & $\mathbf{I}$ \\
\hline i. & HYV/hybrid varieties & $\begin{array}{l}33 \\
(1.41)\end{array}$ & $\begin{array}{l}96 \\
(7.92)\end{array}$ & $\begin{array}{l}28 \\
(6.34)\end{array}$ & $\mathbf{0}$ & $\mathbf{0}$ & $\begin{array}{l}8 \\
(11.42)\end{array}$ & $\mathbf{0}$ & $\mathbf{0}$ & $\begin{array}{l}5 \\
(10.86)\end{array}$ & $\begin{array}{l}170 \\
(3.76)\end{array}$ & \\
\hline ii. & Seed rate and sowing technique & $\begin{array}{l}9 \\
(0.38) \\
\end{array}$ & $\begin{array}{l}140 \\
(11.55) \\
\end{array}$ & $\begin{array}{l}14 \\
(3.17) \\
\end{array}$ & $\mathbf{0}$ & $\begin{array}{l}8 \\
(7.54) \\
\end{array}$ & $\begin{array}{l}4 \\
(5.71) \\
\end{array}$ & $\mathbf{0}$ & $\begin{array}{l}2 \\
(3.84) \\
\end{array}$ & $\begin{array}{l}4 \\
(8.69) \\
\end{array}$ & $\begin{array}{l}181 \\
(4.00) \\
\end{array}$ & \\
\hline iii. & Seed Treatment & $\begin{array}{l}186 \\
(7.94)\end{array}$ & $\begin{array}{l}50 \\
(4.12) \\
\end{array}$ & $\mathbf{0}$ & $\begin{array}{l}9 \\
(5.76)\end{array}$ & $\begin{array}{l}6 \\
(5.66) \\
\end{array}$ & $\begin{array}{l}2 \\
(2.86)\end{array}$ & $\begin{array}{l}3 \\
(3.03) \\
\end{array}$ & $\begin{array}{l}6 \\
(11.53)\end{array}$ & $\begin{array}{l}1 \\
(2.17)\end{array}$ & $\begin{array}{l}263 \\
(5.82) \\
\end{array}$ & \\
\hline iv. & Use of bio fertilizer & $\begin{array}{l}237 \\
(10.13)\end{array}$ & $\begin{array}{l}14 \\
(1.15)\end{array}$ & $\begin{array}{l}1 \\
(0.22) \\
\end{array}$ & $\begin{array}{l}12 \\
(7.69) \\
\end{array}$ & \begin{tabular}{|l|}
8 \\
$(7.54)$ \\
\end{tabular} & $\mathbf{0}$ & $\begin{array}{l}9 \\
(9.09) \\
\end{array}$ & $\begin{array}{l}4 \\
(7.69) \\
\end{array}$ & $\mathbf{0}$ & $\begin{array}{l}285 \\
(6.30) \\
\end{array}$ & \\
\hline v. & (NPK) Fertilizer dose & $\begin{array}{l}39 \\
(1.67)\end{array}$ & $\begin{array}{l}144 \\
(11.88)\end{array}$ & $\begin{array}{l}2 \\
(0.45)\end{array}$ & $\begin{array}{l}6 \\
(3.84)\end{array}$ & $\begin{array}{l}4 \\
(3.77)\end{array}$ & $\begin{array}{l}4 \\
(5.71)\end{array}$ & $\mathbf{0}$ & $\begin{array}{l}4 \\
(7.69)\end{array}$ & \begin{tabular}{|l|}
3 \\
$(6.52)$ \\
\end{tabular} & $\begin{array}{l}206 \\
(4.55) \\
\end{array}$ & \\
\hline vi. & Plant Protection Measure & $\begin{array}{l}165 \\
(7.05)\end{array}$ & $\begin{array}{l}60 \\
(4.95) \\
\end{array}$ & $\begin{array}{l}2 \\
(0.45)\end{array}$ & $\begin{array}{l}3 \\
(1.92)\end{array}$ & $\begin{array}{l}14 \\
(13.20)\end{array}$ & $\mathbf{0}$ & $\begin{array}{l}6 \\
(6.06) \\
\end{array}$ & $\begin{array}{l}6 \\
(11.53) \\
\end{array}$ & $\mathbf{0}$ & \begin{tabular}{|l|}
256 \\
$(5.66)$
\end{tabular} & \\
\hline B. & Availability of Inputs in time & $\begin{array}{l}345 \\
(14.74)\end{array}$ & $\begin{array}{l}356 \\
(29.37)\end{array}$ & $\begin{array}{l}229 \\
(51.92)\end{array}$ & $\begin{array}{l}21 \\
(13.46)\end{array}$ & $\begin{array}{l}18 \\
(16.98)\end{array}$ & $\begin{array}{l}39 \\
(55.71)\end{array}$ & $\begin{array}{l}6 \\
(6.06)\end{array}$ & $\begin{array}{l}10 \\
(19.23)\end{array}$ & $\begin{array}{l}23 \\
(50.00)\end{array}$ & $\begin{array}{l}1047 \\
(23.15)\end{array}$ & III \\
\hline $\mathbf{I}$ & Quality seed in sufficient quantity & $\begin{array}{l}150 \\
(6.41) \\
\end{array}$ & \begin{tabular}{|l|}
56 \\
$(4.62)$ \\
\end{tabular} & $\begin{array}{l}9 \\
(2.04) \\
\end{array}$ & $\begin{array}{l}6 \\
(3.84) \\
\end{array}$ & $\begin{array}{l}2 \\
(1.88)\end{array}$ & $\begin{array}{l}5 \\
(7.14) \\
\end{array}$ & $\mathbf{0}$ & $\begin{array}{l}4 \\
(7.69) \\
\end{array}$ & \begin{tabular}{|l|}
3 \\
$(6.52)$ \\
\end{tabular} & $\begin{array}{l}235 \\
(5.19) \\
\end{array}$ & \\
\hline $\mathbf{I i}$ & Chemical and bio fertilizer & $\begin{array}{l}153 \\
(6.53)\end{array}$ & $\begin{array}{l}40 \\
(3.30)\end{array}$ & $\begin{array}{l}16 \\
(3.62)\end{array}$ & $\begin{array}{l}12 \\
(7.69)\end{array}$ & $\begin{array}{l}2 \\
(1.88)\end{array}$ & $\begin{array}{l}3 \\
(4.28)\end{array}$ & $\begin{array}{l}6 \\
(6.06)\end{array}$ & $\mathbf{0}$ & $\begin{array}{l}3 \\
(6.52)\end{array}$ & $\begin{array}{l}235 \\
(5.19)\end{array}$ & \\
\hline iii. & Plant Protection chemical and impli. & $\begin{array}{l}12 \\
(0.51)\end{array}$ & \begin{tabular}{|l|}
56 \\
$(4.62)$ \\
\end{tabular} & $\begin{array}{l}55 \\
(12.47)\end{array}$ & $\begin{array}{l}3 \\
(1.92) \\
\end{array}$ & $\mathbf{0}$ & $\begin{array}{l}7 \\
(10.00) \\
\end{array}$ & $\mathbf{0}$ & $\mathbf{0}$ & $\begin{array}{l}5 \\
(10.86)\end{array}$ & $\begin{array}{l}138 \\
(3.05) \\
\end{array}$ & \\
\hline iv. & Irrigation facility & $\mathbf{0}$ & $\begin{array}{l}32 \\
(2.64)\end{array}$ & $\begin{array}{l}71 \\
(16.10)\end{array}$ & $\mathbf{0}$ & $\begin{array}{l}2 \\
(1.88)\end{array}$ & $\begin{array}{l}14 \\
(20.00)\end{array}$ & $\mathbf{0}$ & $\mathbf{0}$ & $\begin{array}{l}5 \\
(10.86)\end{array}$ & $\begin{array}{l}124 \\
(2.74)\end{array}$ & \\
\hline v. & Required amount of finance & $\begin{array}{l}18 \\
(0.76) \\
\end{array}$ & $\begin{array}{l}132 \\
(10.89)\end{array}$ & $\begin{array}{l}15 \\
(3.40)\end{array}$ & $\mathbf{0}$ & $\begin{array}{l}2 \\
(1.88)\end{array}$ & $\begin{array}{l}7 \\
(10.00) \\
\end{array}$ & $\mathbf{0}$ & $\mathbf{0}$ & $\begin{array}{l}5 \\
(10.86) \\
\end{array}$ & $\begin{array}{l}179 \\
(3.95) \\
\end{array}$ & \\
\hline vi. & Human and machinery lab. & $\begin{array}{l}12 \\
(0.51)\end{array}$ & \begin{tabular}{|l|}
40 \\
$(3.30)$ \\
\end{tabular} & $\begin{array}{l}63 \\
(14.28)\end{array}$ & $\mathbf{0}$ & $\begin{array}{l}10 \\
(9.43)\end{array}$ & $\begin{array}{l}3 \\
(4.28) \\
\end{array}$ & $\mathbf{0}$ & $\begin{array}{l}6 \\
(11.53)\end{array}$ & $\begin{array}{l}2 \\
(4.34)\end{array}$ & \begin{tabular}{|l|}
136 \\
$(3.01)$ \\
\end{tabular} & \\
\hline $\mathbf{C}$ & Constraints in Market. & $\begin{array}{l}639 \\
(27.31)\end{array}$ & $\begin{array}{l}352 \\
(29.04)\end{array}$ & $\begin{array}{l}133 \\
(30.15)\end{array}$ & $\begin{array}{l}39 \\
(25.00)\end{array}$ & $\begin{array}{l}48 \\
(45.28)\end{array}$ & $\begin{array}{l}11 \\
(15.71)\end{array}$ & $\begin{array}{l}36 \\
(36.36)\end{array}$ & $\begin{array}{l}20 \\
(38.46)\end{array}$ & $\begin{array}{l}\mathbf{8} \\
(\mathbf{1 7 . 3 9})\end{array}$ & $\begin{array}{l}1286 \\
(28.44)\end{array}$ & II \\
\hline 1. & $\begin{array}{l}\text { Roads are well developed to connect } \\
\text { the field with market. }\end{array}$ & $\begin{array}{l}87 \\
(3.71) \\
\end{array}$ & $\begin{array}{l}92 \\
(7.59)\end{array}$ & $\begin{array}{l}12 \\
(2.72)\end{array}$ & $\begin{array}{ll}3 \\
(1.92)\end{array}$ & $\begin{array}{l}10 \\
(9.43)\end{array}$ & $\begin{array}{l}2 \\
(2.85) \\
\end{array}$ & $\begin{array}{ll}6 \\
(6.06)\end{array}$ & $\begin{array}{ll}4 \\
(7.69) \\
\end{array}$ & $\begin{array}{l}1 \\
(2.17) \\
\end{array}$ & $\begin{array}{l}217 \\
(4.79)\end{array}$ & \\
\hline 2. & Transport Are easily available & $\mathbf{0}$ & $\begin{array}{l}8 \\
(0.66) \\
\end{array}$ & $\begin{array}{l}83 \\
(18.12) \\
\end{array}$ & $\mathbf{0}$ & $\begin{array}{l}2 \\
(1.88) \\
\end{array}$ & $\begin{array}{l}7 \\
(\mathbf{1 0 . 0 0 )} \\
\end{array}$ & $\mathbf{0}$ & $\mathbf{0}$ & $\begin{array}{l}5 \\
(10.86) \\
\end{array}$ & $\begin{array}{l}105 \\
(2.32) \\
\end{array}$ & \\
\hline 3. & MSP is remuner. Enough & $\begin{array}{l}162 \\
(6.92) \\
\end{array}$ & $\begin{array}{l}50 \\
(4.12) \\
\end{array}$ & $\begin{array}{l}8 \\
(1.81) \\
\end{array}$ & $\begin{array}{l}9 \\
(5.76) \\
\end{array}$ & $\begin{array}{l}10 \\
(9.43)\end{array}$ & $\mathbf{0}$ & $\begin{array}{l}9 \\
(9.09)\end{array}$ & $\begin{array}{l}4 \\
(7.69) \\
\end{array}$ & $\mathbf{0}$ & $\begin{array}{l}252 \\
(5.57) \\
\end{array}$ & \\
\hline 4. & Govt. Purchase prod. At MSP & $\begin{array}{l}234 \\
(10)\end{array}$ & $\begin{array}{ll}18 \\
(1.48)\end{array}$ & $\mathbf{0}$ & $\begin{array}{l}21 \\
(13.46)\end{array}$ & $\begin{array}{ll}2 \\
(1.88)\end{array}$ & $\mathbf{0}$ & $\begin{array}{l}15 \\
(15.15)\end{array}$ & $\mathbf{0}$ & $\mathbf{0}$ & $\begin{array}{l}290 \\
(6.41)\end{array}$ & \\
\hline 5. & $\begin{array}{l}\text { Village traders Purchase the produce } \\
\text { at profitable price }\end{array}$ & $\begin{array}{l}87 \\
(3.71)\end{array}$ & $\begin{array}{l}114 \\
(9.40)\end{array}$ & $\begin{array}{l}1 \\
(0.22)\end{array}$ & $\begin{array}{l}3 \\
(1.92)\end{array}$ & $\begin{array}{l}14 \\
(13.20)\end{array}$ & $\mathbf{0}$ & $\begin{array}{l}6 \\
(6.06) \\
\end{array}$ & $\begin{array}{l}6 \\
(11.54)\end{array}$ & $\mathbf{0}$ & $\begin{array}{l}231 \\
(5.11)\end{array}$ & \\
\hline 6. & $\begin{array}{l}\text { Regulated markets fairly facilitate the } \\
\text { sale and protect the farmers' interest }\end{array}$ & $\begin{array}{l}69 \\
(2.95)\end{array}$ & $\begin{array}{l}70 \\
(5.77)\end{array}$ & $\begin{array}{l}29 \\
(6.57)\end{array}$ & $\begin{array}{l}3 \\
(1.92)\end{array}$ & $\begin{array}{l}10 \\
(9.43)\end{array}$ & $\begin{array}{l}2 \\
(2.86)\end{array}$ & $\mathbf{0}$ & $\begin{array}{l}6 \\
(11.54)\end{array}$ & $\begin{array}{l}2 \\
(4.34)\end{array}$ & $\begin{array}{l}191 \\
(4.22)\end{array}$ & \\
\hline D & Any other problems & $\begin{array}{l}687 \\
(29.36)\end{array}$ & $\mathbf{0}$ & $\begin{array}{l}32 \\
(7.25)\end{array}$ & $\begin{array}{l}66 \\
(42.30)\end{array}$ & $\mathbf{0}$ & $\begin{array}{l}2 \\
(2.86)\end{array}$ & $\begin{array}{l}39 \\
(39.39)\end{array}$ & $\mathbf{0}$ & $\begin{array}{l}2 \\
(4.34)\end{array}$ & $\begin{array}{l}828 \\
(18.31)\end{array}$ & IV \\
\hline i. & Blue Bull & $\begin{array}{l}261 \\
(11.15)\end{array}$ & $\mathbf{0}$ & 0 & $\begin{array}{l}24 \\
(15.38)\end{array}$ & $\mathbf{0}$ & $\mathbf{0}$ & $\begin{array}{l}15 \\
(15.15)\end{array}$ & $\mathbf{0}$ & 0 & $\begin{array}{l}300 \\
(6.63)\end{array}$ & \\
\hline ii. & Natural calamity & $\begin{array}{l}261 \\
(11.15) \\
\end{array}$ & $\mathbf{0}$ & $\mathbf{0}$ & $\begin{array}{l}24 \\
(15.38)\end{array}$ & $\mathbf{0}$ & $\mathbf{0}$ & $\begin{array}{l}15 \\
(15.15) \\
\end{array}$ & $\mathbf{0}$ & $\mathbf{0}$ & $\begin{array}{l}300 \\
(6.63) \\
\end{array}$ & \\
\hline iii. & Cannal Problem & $\begin{array}{l}165 \\
(7.05)\end{array}$ & $\mathbf{0}$ & $\begin{array}{l}32 \\
(7.25)\end{array}$ & $\begin{array}{l}18 \\
(11.54)\end{array}$ & $\mathbf{0}$ & 2 & $\begin{array}{l}9 \\
(9.09)\end{array}$ & $\mathbf{0}$ & $\begin{array}{l}2 \\
(4.34)\end{array}$ & $\begin{array}{l}228 \\
(5.04)\end{array}$ & \\
\hline & & 2340 & 1212 & 441 & 156 & 106 & 70 & 99 & 52 & 46 & 4522 & \\
\hline
\end{tabular}

The prices of the pulses in different mandies should be published in the newspapers for information to the farmers.

Co-operative marketing societies should be functioning in the area in order to help the farmers for storage and selling of produce at remunerative prices.

Besides these suggestion given by the respondents the investigator suggest that the farmers may come forward to solve their 
many problems related with production and marketing.

They should regularly contact with the extension person to solve their problems of technical knowledge.

They can from the SHG to manage their financial problems and problem of processing and marketing of pulses.

For regular information of different Govt. plans launched for the farmers benefit, they can contact the Kisan call centre at No. 18001801551 and the IFFCO Kisan call centre No. 534351.

It is concluded that the problems of production and marketing can be solved through joint effect of farmers as well Govt. agencies

\section{References}

Amutha, D. (2011). Constraints and techniques for improving pulses production in Tamil Nadu, India. Banaras Hindu University - CAB Abstracts International Journal of Bioresource and Stress Management. 2(2):159-162.

Burman, R. R. Singh, S. K. Lakhan Singh Singh, A. K. (2006). Adoption of improved pulses production technologies and related constraints in Uttar Pradesh. Indian Journal of Pulses Research., 2006. 19(1):104-106.

Gupta, S.K. (2001). Economics of pulses production and identification of constraints in raising their production (a consolidated report of AERC studies).Ad-hoc study-Agro-Economics Research Centre for Madhya Pradesh, Jawaharlal Nehru Krishi Vishwa Vidyalaya, 2001. 79, 177.

Khatiwada, M. K. Poudel, S. K. Gurung, D. K. (1988). Socio economic constraints to pulse production in Nepal. CGPRT Publication; 1988. 18: xi80.

\section{How to cite this article:}

Rajeev Singh, Gyan Prakesh Singh, Praveen Kumar Sahu and Avanish Kumar Singh. 2017. A Study on Constraints in Production and Marketing of Pulses and Suggest Suitable Policy Measures. Int.J.Curr.Microbiol.App.Sci. 6(8): 762-768.

doi: https://doi.org/10.20546/ijcmas.2017.608.097 